\title{
Defective suppression in the autologous mixed lymphocyte reaction in patients with Crohn's disease
}

\author{
D Kelleher, A MURPHY, C A WHELAN, C FEIGHERY, D G WEIR, \\ AND $P$ W N KEELING \\ From the Departments of Clinical Medicine and Immunology, Trinity College Dublin, Medical School and St \\ James' Hospital, Dublin
}

SUMMARY T helper and suppressor cell control of autologous immunoglobulin production was measured in 14 patients with Crohn's disease (CD) using autologous B cells or monocytes to stimulate regulatory T-cell activity. A pronounced defect in suppressor cell function was observed in the patient group but not in matched controls irrespective of whether B cells or monocytes were used as the stimulus. This defect was observed for IgG,A and M. This defect was seen both in patients with active disease and with inactive $C D$ suggesting the possibility that a primary regulatory defect might exist in this disease. The patient group displayed normal helper cell function.

The autologous mixed lymphocyte reaction (AMLR) is an in vitro proliferative response that occurs when isolated $T$ cells are cocultured with autologous non- $T$ cells - for example, B cells or monocytes - expressing class II major histocompatibility complex (MHC) antigens. ${ }^{1} \mathrm{~T}$ cells activated in the AMLR are designated autoreactive $\mathrm{T}$ cells (Ta) and function predominately as suppressor cells ${ }^{2-4}$ for such functions as $T$ cell proliferation and $T$ cell assisted $B$ cell immunoglobulin production. ${ }^{5}$ Recent work has suggested that the generation of suppression in the AMLR may represent an in vivo feedback inhibition mechanism in the regulation of activated lymphocyte proliferation. ${ }^{\circ}$ This reaction has both memory and specificity.

Defects in the AMLR have been described in conditions such as systemic lupus erythematosis,? primary biliary cirrhosis, ${ }^{8}$ Sjogren's syndrome, ${ }^{9}$ and autoimmune thrombocytopenic purpura. ${ }^{10}$ Abnormal $\mathrm{T}$ cell suppression has been reported in inflammatory bowel disease using concanavalin A (con A) generated short lived suppressor cells. ${ }^{11}$ Auer $e t$ al have shown that in patients with active, but not inactive Crohn's disease, there is impaired sup-

Address for correspondence: Dr D Kelleher, Trinity College Dublin Medical School, St James' Hospital, Dublin 8, Ireland.

Accepted for publication 8 November 1988. pression of lymphocyte proliferation in the con A generated irradiated suppressor cell assay and in the spontaneous suppressor cell assay. ${ }^{12}$ Defective suppression might explain such features as lymphocyte cytotoxicity for colonic epithelial cells ${ }^{13}$ and increased immunoglobulin secretion by colonic B lymphocytes. ${ }^{14}$ The aims of our study were to examine the generation of help and suppression of B cell immunoglobulin secretion by peripheral blood $\mathrm{T}$ lymphocytes activated by autologous accessory cells. As the AMLR is highly sensitive to corticosteroid therapy, ${ }^{515}$ patients studied were not using steroids.

\section{Methods}

PATIENTS

We studied 14 patients with Crohn's disease and 14 normal age matched controls. Six patients were aged 15-30 years, five 30-45, two 45-60, and one over 60 . Patients did not receive corticosteroids for at least three weeks before and during the study period. Five patients were receiving sulphasalazine during the study. Three patients had colonic disease, five ileocolonic and six ileal disease Six patients had active disease requiring inpatient hospital management at the time of the study and eight patients were asymptomatic with inactive disease. Two patients 
had had previous surgery, one a total colectomy, and the second a right hemicolectomy. No patients were studied who were anaemic. One patients was hypoalbuminaemic but disease was otherwise clinically inactive. Two of these patients were malnourished (body weight $<10$ th percentile for height and age) at the time of study.

AUTOLOGOUS MIXED LYMPHOCYTEREACTION Peripheral blood mononuclear cells were isolated from fresh heparinised venous blood obtained from patients and controls by density centrifugation on Ficoll-Paque (Pharmacia) gradients. All samples were drawn in the early morning to avoid circadian variation. Cells were suspended in PRMI 1640 medium containing $20 \mathrm{mM}$ l-glutamine, gentamicin $20 \mathrm{mM}$, and $10 \%$ fetal calf serum. The cell suspension was cultured in plastic flasks (Flow Laboratories) to deplete adherent cells and monocytes were harvested from plastic by scraping with a rubber policeman. The monocyte depleted suspension was then passed through two sequential nylon wool columns to obtain a purified $T$ cell population. B cells were harvested by agitation of the nylon wool columns. Purity was assessed using monoclonal antibodies to monocytes (MO2, Coulterclone) (80-85\% pure), T cells (Leu 1a Becton Dickinson) (95-98\% pure), and B cells (B1, Coulterclone) (60-65\% pure). The remaining cells in the $\mathrm{B}$ cell fraction were null cells and $10-20 \%$ T cells.

PRIMARY CULTURE

\section{Generation of autoreactive T cells}

The AMLR was carried out by incubating $2 \times 10^{h} \mathrm{~T}$ cells with $1 \times 10^{6}$ irradiated $B$ cells or $1 \times 10^{6}$ irradiated monocytes per well or medium alone in a total volume of 2 mls of supplemented RPMI 1640 in 24 well tissue culture plates (Linbro, Flow Laboratories). Cultures of $\mathrm{B}$ cells, monocytes or $\mathrm{T}$ cells alone were set up as controls. Cells were incubated at $37^{\circ} \mathrm{C}$ in a humidified $\mathrm{CO}_{2}$ incubator for seven days. They were then harvested, washed and counted before addition to the secondary culture which functioned as the indicator system for help and suppression. Ta cells activated by monocytes are designated $T_{M}$ and by $B$ cells as $T_{B}$.

\section{SECONDARY CULTURE}

\section{Indicator system}

On day 7 patients and controls were again venesected and the heparinised blood was then fractionated into individual cell types as described above. T cells were divided into two fractions, one of which $\left(T_{x}\right)$ was irradiated (2500 rads) to deplete suppressor cells and block proliferation, while the other cells were used untreated. cells from the primary culture $\left(1 \times 10^{\dagger} / \mathrm{ml}\right)$ were then added to the secondary culture in 96 well microtitre round bottom plates to a final volume of $200 \mu \mathrm{l}$. Twenty microlitres of pokeweed mitogen (Sigma) at a final dilution of 1:200 were added to each well. Culture supernatants were coded and assayed blindly for $\operatorname{IgG}$, IgA, and IgM using enzyme linked immunosorbent assay (ELISA) as previously described.$^{16}$ Help was assayed by measuring the increase in immunoglobulin synthesis when $T_{A}$ cells $\left(T_{B}\right.$ or $T_{M}$ ) were added to fresh $B$ cells. When autoreactive $T$ cells were added to cultures containing $T_{x}$ and $B$ cells, quantitation of the reduction from the maximal immunoglobulin secretion allowed assay of suppression.

\section{CALCULATIONS AND STATISTICS}

Immunoglobulin production is expressed as mean and standard deviation of $\mathrm{ng} / \mathrm{ml}$ immunoglobulin isotype produced. Student's $t$ test was used for statistical analysis. Suppression of immunoglobulin secretion was calculated using the formula:

$$
\% \text { Suppression }=100 \times 1-\frac{[\mathrm{Ta}+(\mathrm{Tx}+\mathrm{B})]}{(\mathrm{Tx}+\mathrm{B})}
$$

where $\mathrm{Ta}+(\mathrm{Tx}+\mathrm{B})$ is the immunoglobulin production by $B$ cells in the presence of irradiated $T$ cells and added autoreactive T cells. Help was calculated from the formula

$$
\% \text { Help }=100 \times 1-\frac{[\mathrm{B} \text { alone }]}{(\mathrm{Ta}+\mathrm{B})}
$$

where $B$ represents immunoglobulin secretion by $B$ cells alone and $\mathrm{Ta}+\mathrm{B}$ represents immunoglobulin

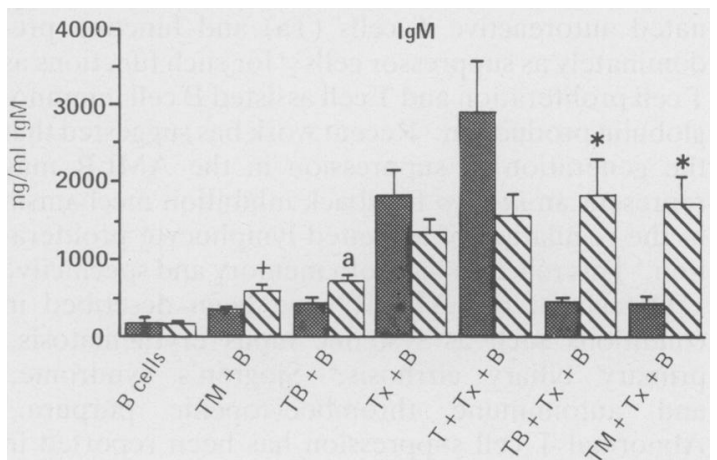

Fig. 1 IgM secretion by $B$ cells under various conditions. $T M$ and TB are T cells activated in the AMLR by monocytes and $B$ cells respectively. $T X$ are fresh irradiated $T$ cells and $T$ are fresh $T$ cells which have not been incubated in an $A M L R$ and which have not been irradiated. Statistical significance is designated as follows. a: $p<0.01,+: p<0.001,{ }^{*}: p<0.0001$. Solid bars represent normal controls: hatched bars Crohn's disease. 


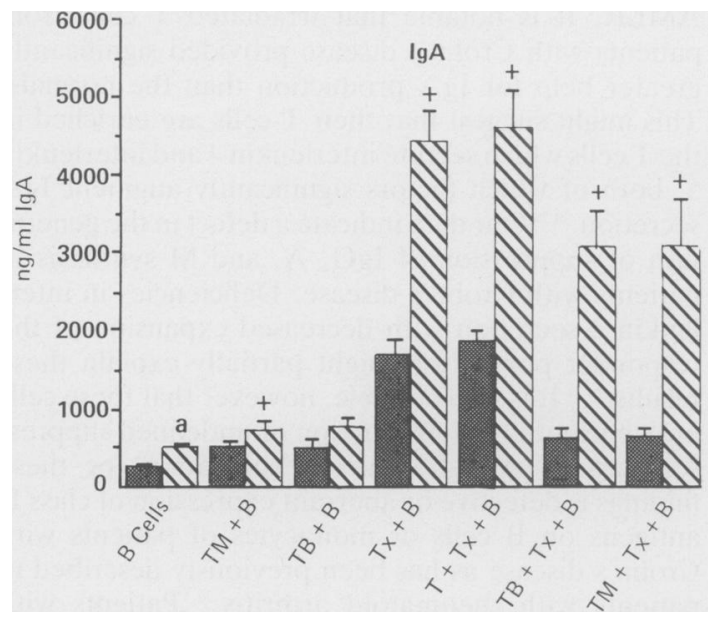

Fig. 2 IgA secretion by $B$ cells under varying co-culture conditions. Abbreviations and statistical significance are as outlined in the legend to Fig. 1.

production on addition of autoreactive $T$ cells. Results of percentage help and suppression are expressed as median and range. Statistics were calculated using the Mann-Whitney test.

\section{Results}

HELP FOR IMMUNOGLOBULIN PRODUCTION $B$ cell IgM production in the presence of autoreactive $\mathrm{T}$ cells $(\mathrm{Tb}$ or $\mathrm{Tm})$ was significantly higher in patients with $C D$ relative to normal controls whether $T$ cells were activated with B cells or monocytes (Fig. 1). IgA production by isolated $B$ cells was significantly enhanced in patients with CD (Fig. 2). IgA production in the presence of TM was also enhanced. There were no significant differences in quantity of

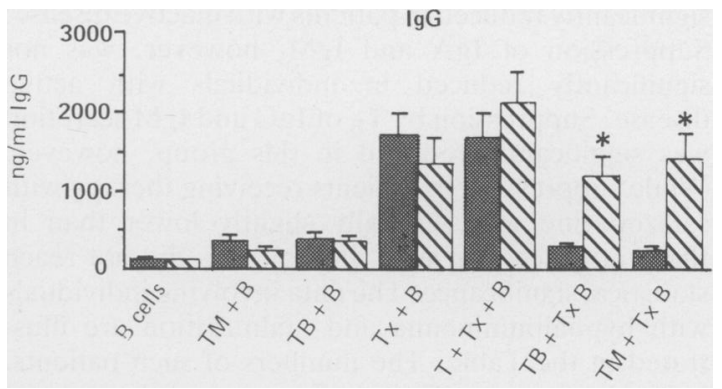

Fig. 3 IgG secretion by $B$ cells under varying co-culture conditions. Abbreviations and statistical significance are as outlined in the legend to Fig. 1.

IgG secretion (Fig. 3) between individuals with CD and normal controls when autoreactive $T$ cells were added. Monocytes alone added to $B$ cells did not significantly alter immunoglobulin secretion (data not shown). When irradiated $T$ cells were added to $B$ cells, IgA (Fig. 2) but not IgG or IgM secretion was significantly enhanced relative to controls. The percentage help by TB and TM for IgG, $A$, and $M$ in patients with $C D$ did not differ significantly from controls (data not shown).

\section{SUPPRESSION OF IMMUNOGLOBULIN}

PRODUCTION BY AUTOREACTIVET CELLS

Addition of irradiated $\mathrm{T}$ cells significantly enhanced immunoglobulin production by $B$ lymphocytes $(\mathrm{Tx}+\mathrm{B})$ in patients with Crohn's disease and normal controls (Figs 1, 2, 3). Addition of autoreactive $T$ cells $\left(T_{B}\right.$ and $\left.T_{M}\right)$ to this system markedly reduced IgM, IgA, and IgG secretion in normal controls but not in CD (Figs 1,2,3). Furthermore, the percentage suppression of IgG, IgA, and IgM production by $T_{B}$ and $T_{M}$ was significantly reduced relative to controls (Table). Suppression of all isotypes by $T_{M}$ was

Table Suppression by Ta cells

\begin{tabular}{|c|c|c|c|c|c|c|c|c|}
\hline & $N C+$ & $C D \ddagger$ & $C D$ active & $C D$ inactive & $S P \S$ & No sp & Low alb & Malnutrition \\
\hline $\mathrm{IgG} / \mathrm{Tm}$ & $90(1-99)$ & $\begin{array}{l}24(0-75) \\
\mathrm{p}<0.01\end{array}$ & $\begin{array}{l}21 \cdot 5(0-50) \\
p<0.001\end{array}$ & $\begin{array}{l}27 \cdot 5(0-75) \\
p<0 \cdot 001\end{array}$ & $\begin{array}{r}6(0-75) \\
p<0.001\end{array}$ & $\begin{array}{l}26(0-50) \\
p<0.001\end{array}$ & 0 & 17,49 \\
\hline $\mathrm{IgG} / \mathrm{Tb}$ & $86(0-97)$ & $\begin{array}{l}29(0-77) \\
p<0.001\end{array}$ & $\begin{array}{l}52(5-69) \\
\mathrm{p}<0.01\end{array}$ & $\begin{array}{l}29.5(0-75) \\
\mathrm{p}<0.001\end{array}$ & $\begin{array}{l}11(0-77) \\
p<0.02\end{array}$ & $\begin{array}{l}29(5-69) \\
p<0 \cdot 00\end{array}$ & 0 & 21,52 \\
\hline IgM/Tm & $75 \cdot 5(5-94)$ & $\begin{array}{l}39(0-73) \\
\mathrm{p}<0.01\end{array}$ & $\begin{array}{l}58(0-73) \\
\text { NS }\end{array}$ & $\begin{array}{l}19.5(0-64) \\
p<0.001\end{array}$ & $\begin{array}{l}22(0-61) \\
p<0.01\end{array}$ & $\begin{array}{l}51(0-73) \\
\mathrm{p}<0.01\end{array}$ & 22 & 17,61 \\
\hline $\mathrm{IgM} / \mathrm{Tb}$ & $70(0-90)$ & $\begin{array}{l}36(0-76) \\
p<0.001\end{array}$ & $\begin{array}{l}41.5(0-51) \\
\mathrm{p}<0.002\end{array}$ & $\begin{array}{l}29(0-76) \\
p<0.001\end{array}$ & $\begin{array}{l}17(0-32) \\
\mathrm{p}<0.001\end{array}$ & $\begin{array}{l}44(0-76) \\
p<0.002\end{array}$ & 28 & 32,43 \\
\hline $\operatorname{IgA} / \mathrm{Tm}$ & $59(3-90)$ & $\begin{array}{l}25(6-75) \\
p<0.02\end{array}$ & $\begin{array}{l}59(18-75) \\
\mathrm{p}<0.05\end{array}$ & $\begin{array}{l}15(6-30) \\
p<0.02\end{array}$ & $\begin{array}{l}18(6-59) \\
p<0.05\end{array}$ & $\begin{array}{l}30(12-75) \\
\mathrm{p}<0.05\end{array}$ & 14 & 75,59 \\
\hline $\operatorname{IgA} / \mathrm{Tb}$ & $69(17-35)$ & $\begin{array}{l}30 \cdot 5(17-70) \\
\mathrm{p}<0 \cdot 001\end{array}$ & $\begin{array}{l}38(25-70) \\
\text { NS }\end{array}$ & $\begin{array}{l}27(17-40) \\
p<0.001\end{array}$ & $\begin{array}{l}31(22-38) \\
p<0.005\end{array}$ & $\begin{array}{l}30(17-70) \\
\mathrm{p}<0.01\end{array}$ & 31 & 70,38 \\
\hline
\end{tabular}

*Expressed as median and range ( ) percentage suppression as derived from formula in Methods; †NC - normal controls; $\ddagger \mathrm{CD}-\mathrm{Crohn}$ 's disease; §SP Salazopyrine. 
significantly reduced in patients with inactive disease. Suppression of $\operatorname{IgA}$ and $\operatorname{IgM}$, however, was not significantly reduced in individuals with active disease. Suppression by $T_{B}$ of IgG and IgM secretion was significantly reduced in this group, however. While suppression in patients receiving therapy with salazopyrine was generally slightly lower than in those not receiving such therapy, this did not reach statistical significance. The data involving individuals with hypoalbuminemia and malnutrition are illustrated in the Table. The numbers of such patients, however, are insufficient for statistical analysis. Neither individually precultured T cells, B cells, or monocyte controls significantly altered immunoglobulin production in this system (data not shown).

\section{Discussion}

Immunoregulatory defects may play a role in the pathogenesis of chronic autoimmune and inflammatory processes. In this study we have utilised the AMLR in which the autologous class II antigens on B cells and monocytes stimulate $\mathrm{T}$ cell proliferation. While the physiological importance of the AMLR has not been fully elucidated, the establishment of cloned lines of autoreactive cells clearly establishes that there is a subset of cells in peripheral blood which respond to autologous class II antigens by proliferation or by cytotoxicity. ${ }^{17-19}$ This population is xenoantigen independent ${ }^{20-22}$ although it may be augmented by xenoantigen in certain individuals who have previously been sensitised. ${ }^{22}$ While suppression is ultimately the dominant effector mechanism generated in the seven day AMLR, it has been demonstrated that the responder cell lies within the CD4 positive $T$ cell population..$^{2623} \mathrm{~A}$ subpopulation of $\mathrm{CD} 4$ positive cells with suppressor inducer properties has been identified using a variety of monoclonal antibodies. ${ }^{23}$ Furthermore it has been demonstrated using depletion studies that AMLR inducible and con A inducible suppressor cells lie within the same population. ${ }^{+}$

In this study, we have examined the generation of help and suppression of pokeweed mitogen driven immunoglobulin secretion by $T$ cells activated in the seven day AMLR. T cells from normal individuals stimulated in the AMLR clearly suppress immunoglobulin secretion by B cells cultured with fresh irradiated T cells. This effect requires the presence of maximal help provided by fresh irradiated $T$ cells and is not seen when fresh T cells not stimulated in the AMLR (non-irradiated) are added. By contrast, the help generated by activated autoreactive $T$ cells for immunoglobulin secretion is not maximal, suggesting that the population of $T$ cells providing help for immunoglobulin secretion is not expanded in the
AMLR. It is notable that irradiated $T$ cells from patients with Crohn's disease provided significantly greater help for $\operatorname{IgA}$ production than the normals. This might suggest that their $\mathrm{T}$ cells are enriched in the $T$ cells which secrete interleukin 4 and interleukin 5 , both of which factors significantly augment $\operatorname{IgA}$ secretion. ${ }^{24}{ }^{25}$ Our data indicate a defect in the generation of suppression of $\operatorname{IgG}, A$, and $M$ synthesis in patients with Crohn's disease. Deficiencies in interleukin 2 secretion with decreased expansion of the responder population might partially explain these results. ${ }^{2627}$ It is also possible, however that these cells are deficient in the production of undefined suppressor factors. An alternative explanation for these findings is defective or aberrant expression of class II antigens on B cells or monocytes of patients with Crohn's disease as has been previously described in patients with rheumatoid arthritis. ${ }^{28}$ Patients with active Crohn's disease have increased expression of DR antigen on intestinal epithelial cells ${ }^{24}$ and it is possible that pre-activation, by contact with these or other cells may enhance the generation of $T$ cell suppression in this group of patients.

In a previous study of proliferative responses in the AMLR in inflammatory bowel disease, McDermott et al showed normal responses in the seven day AMLR. ${ }^{30}$ Of note, however, is the fact that reduced responses were noted in six day cultures in patients with inactive disease. It is clear, however, that there are major technical differences between our studies. These findings of normal proliferative responses in the seven day AMLR are not inconsistent with our data because the generation of lymphokines by $T$ cells is not dependent on proliferation. Our study examines the generation of functional responses and not proliferative responses in the AMLR. Two studies have shown, however, reduced proliferative responses in the AMLR in patients with CIBD ${ }^{26.31}$ which were associated with reduced numbers of IL2 receptors on circulating $\mathrm{T}$ cells in one study. ${ }^{26}$ The defective proliferation was partially reversed by addition of interleukin 2. It is of note that IL2 secretion by intestinal mononuclear cells has been shown to be reduced in CIBD. ${ }^{27}$ Ginsburg and Falchuk have also shown decreased suppression of the allogeneic mixed lymphocyte response by $\mathrm{T}$ cells activated in an autologous mixed lymphocyte response in six patients with inflammatory bowel disease. ${ }^{31}$

The aetiology of defective suppression in patients with CIBD is unexplained. Genetic factors could play a role but studies of HLA haplotypes in inflammatory bowel disease have not shown convincing evidence of disease association. Crohn's disease has been associated with particular immunoglobulin allotypes.$^{32}$ It is difficult, however, to associate this with a $\mathrm{T}$ cell 
defect. An alternative hypothesis is that a selective lymphotropic agent may deplete a particular subset of $T$ cells in these patients. While, this pattern of depletion has been shown in HIV infection, ${ }^{33}$ lymphocyte subsets, including numbers of the suppressor inducer subset appear to be normal in patients with Crohn's disease. ${ }^{34} \mathrm{~A}$ further possibility is that lymphocytophilic antibodies may functionally interfere with a subpopulation of $\mathrm{T}$ lymphocytes. Finally it is possible that this defect which is apparent in peripheral blood may reflect a mirror image of what is occurring at the intestinal level. Thus migration of a subset of suppressor lymphocyte to the intestine may deplete the peripheral circulation of these cells. In this regard, it is notable that intestinal epithelial cells are capable of presenting antigen to $T$ lymphocytes and appear to selectively activate suppressor cells. ${ }^{35}$ Our finding that this defect is more marked in patients with inactive disease in this study, however, suggests that this defect is not based on intestinal $\mathrm{T}$ cell migration.

Defects in suppression have been implicated in the pathogenesis of autoimmune disease such as systemic lupus erythematosis. Defective suppression could allow the persistence of an uncontrolled immune response even when the antigenic stimulus has been removed. In this regard it is notable that transfer of suppressor T lymphocyte clones is capable of inhibiting the development of disease in animal models of autoimmune disease, such as experimental allergic encephalomyelitis and adjuvant arthritis. ${ }^{36.37}$ The mucosal immune system has important suppressor functions inhibiting unwanted systemic immunological responses to environmental antigens. ${ }^{38}$ Defective suppression in the AMLR may indicate an immunoregulatory imbalance at the mucosal level, which could permit persistence of an inflammatory response induced by resident or ingested antigens.

\section{References}

1 Weksler ME, Moody CE, Kozak. The autologous mixed lymphocyte reaction. Adv Immunol 1981; 31: 271-313.

2 Gocken NE, Melton ZJ. Immunoregulatory activity of T-cell subset activated in human mixed lymphocyte reaction. Hum Immunol 1983; 6: 79-90.

3 Sakane TE, Greene I. Human suppressor T cells induced by Concanavalin A: Suppressor T cells belong to distinctive T cell subclasses. J Immunol 1977; 119: 1169-75.

4 Innes JB, Kuntz MM, Kim YT, Weksler ME. Induction of suppressor activity in the autologous mixed lymphocyte reaction and in cultures with Concanavalin A. J Clin Invest 1979; 64: 1608-13.

5 James SP, Yenokida GG, Graeff AS, Elson CO, Strober W. Immunoregulatory function of $\mathrm{T}$ cells activated in the autologous mixed lymphocyte reaction. J Immunol 1981; 127: 2605-9.
6 Kotani H, Takada S, Veda Y, Murakawa Y, Suzuki N, Sakane $T$. Activation of immune regulatory circuits among OKT4 cells by autologous mixed lymphocyte reactions. Clin Exp Immunol 1984; 56: 390-405.

7 Takada S, Veda Y, Suzuki N, et al. Abnormalities in autologous mixed lymphocyte reaction activated immunological processes and their possible correction by interleukin 2. Eur J Immunol 1985; 15: 262-7.

8 James SP, Elson CD, Waggoner JG, Jones A, Strober W. Deficiency of the autologous mixed lymphocyte reaction in primary biliary cirrhosis. J Clin Invest 1980; 66: $1305-10$.

9 Miyasaka N, Sauvezie B, Pierce DA, Daniels TE, Talal $\mathrm{N}$. Decreased autologous mixed lymphocyte reaction in Sjogren's syndrome. J Clin Invest 1980; 66: 928-33.

10 Zinburg M, Francus T, Weksler ME, Siskind GW, Kapratkin S. Abnormal autologous mixed lymphocyte reaction in autoimmune thrombocytopenic purpura. Blood 1982; 59: 148-51.

11 Hodgson HJF, Wands JR, Isselbacher KJ. Decreased suppressor cell activity in inflammatory bowel disease. Clin Exp Immunol 1978; 32: 451-8.

12 Auer ID, Roder AA, Frohlich J. Immune status in Crohn's disease VI. Immunoregulation evaluated by multiple distinct T-suppressor cell assays of lymphocyte proliferation and by enumeration of immunoregulatory T-lymphocyte subsets. Gastroenterology 1984; 86: 1531-43.

13 Kemler BJ, Alpert E. Inflammatory bowel disease: Study of cell mediated cytotoxicity for isolated colonic epithelial cells. Gut 1980; 21: 353-9.

14 Bookman MA, Bull DM. Characteristics of isolated intestinal mucosal lymphoid cells in inflammatory bowel disease. Gastroenterology 1979; 77: 503-10.

15 Hahn BH, MacDermott RP, Jacobs SB, Pletscher LS, Beale MG. Immunosuppressive effects of low dosage of glucocrticoids: Effects on autologous and allogeneic mixed lymphocyte reactions. J Immunol 1980; 124: 2812-7.

16 McKeever U, O’Mahony C, Whelan CA, Weir DG, Feighery C. Helper and suppressor $T$ lymphocyte function in severe alcoholic liver disease. Clin Exp Immunol 1985; 60: 39-48.

17 Kotani H, Mitsuya H, Jarrett RF, Yenokida GG, James SP, Strober W. An autoreactive T cell clone that can be activated to provide both helper and suppressor activity. J Immunol 1986; 136: 1951-9.

18 Finnegan A, Needleman B, Hodes RJ. Activation of B cells by cloned autoreactive $\mathrm{T}$ cells: cloned autoreactive $\mathrm{T}$ cells activate $\mathrm{B}$ cells by two distinct pathways. J Immunol 1984; 133: 78-85.

19 Bensussan A, Meur SC, Schlossman SF, Reinherz EL. Delineation of an immunoregulatory amplifier population recognizing autologous Ia molecules: analysis with T cell clones. J Exp Med 1984; 159: 559-71.

20 Naides SJ, Redelman D, Zvaifler NJ. The role of xenoantigen in the human autologous mixed lymphocyte reaction: ability to respond in the absence of exposure to xenoantigen depends on the method of $T$ cell preparation. Clin Immunol Immunopathol 1985; 34: 216-26.

21 Laffon A, Alcocer-Varela J, Alarcon-Segovia D. The 
autologous mixed lymphocyte reaction is not primarily due to xenoantigenic stimulation. Clin Immunol Immunopathol 1983; 28: 304-8.

22 Moody CE, Gupta S, Weksler ME. Lymphocyte transformation induced by autologous cells. XV. Xenoantigens are not required for the proliferative response observed in the autologous mixed lymphocyte reaction. J Clin Immunol 1983; 3: 100-2.

23 Romain PL, Mortimoto C, Daley JF, Palley LS, Reinherz EL, Schlossman SF. Reactivity of inducer cell subsets and T8 cell activation during the autologous mixed lymphocyte reaction. Clin Immunol Immunopathol 1984; 30: 117-28.

24 Murray PD, McKenzie DT, Swain SL, Kagnoff MF. Interleukin 5 and interleukin 4 produced by Peyer's patch $\mathrm{T}$ cells selectively enhance Immunoglobulin A secretion. J Immunol 1987; 139: 2669-75.

25 Mossman TR, Cherwinski H, Bond MW, Giedlin MA, Coffman RL. Two types of helper $T$ cell clones. I. Definition according to profile of lymphokine activities and secreted proteins. J Immunol 1986; 136: 2348-57.

26 Ebert EC, Wright SH, Lipshutz WH, Hamptman SP. Tcell mediated abnormalities in inflammatory bowel disease are mediated by interleukin 2. Clin Immunol Immunopathol 1984; 33: 232-44.

27 Fiocchi C, Hilfiker ML, Youngman KR, Doerder NC, Finke JH. Interleukin 2 activity of human intestinal mononucler cells. Gastroenterology 1984; 86: 734-42.

28 Hassan J, Feighery C, Bresnihan B, Whelan A. Abnormal HLA DR antigen expression on monocyte membranes of patients with active rheumatoid arthritis. Br J Rheumatol 1986; 25: 102.

29 Selby WS, Janossy G, Mason DW, Jewell DP. Expression of HLA-DR antigens by colonic epithelium in inflammatory bowel disease. Clin Exp Immunol 1983; 53: $614-8$.
30 MacDermott RP, Bragdon MJ, Thusmond RD. Peripheral blood mononuclear cells exhibit normal function in the allogeneic and autologous mixed lymphocyte reaction and cell mediated cytolysis. Gastroenterology 1984; 86: 476-85.

31 Ginsburg CA, Falchuk SM. Defective autologous mixed lymphocyte reaction and suppressor cell generation in patients with inflammatory bowel disease. Gastroenterology 1982; 83: 1-9.

32 Kagnoff MF, Brown RJ, Schanfield MS. Association between Crohn's disease and immunoglobulin heavy chain $(\mathrm{Gm})$ allotypes. Gastroenterology 1983; 85: 1044-7.

33 Levy JA, Hoffman AAD, Kramer SM, Landis JA, Shimbukuro JM. Isolation of lymphocytotrophic retrovirus from San Francisco patients with AIDS. Science 1984; 225: 840-2.

34 Roche JK, Watkins MH, Cook SL. Inflammatory bowel disease: prevalence and level of activation of circulating T-lymphocyte subpopulations mediating suppressor/ cytotoxic and helper function as defined by monoclonal antibodies. Clin Immunol Immunopathol 1983; 25: 36273.

35 Mayer L, Shlien R. Evidence for function of Ia molecules on gut epithelial cells in man. $J$ Exp Med 1987; 166: $1471-83$.

36 Cohen IR. Regulation of autoimmune disease; physiological and therapeutic. Immunol Rev 1986; 94: 5-21.

37 Ellerman KE, Powers JM, Brostoff SW. A suppressor T-lymphocyte line for autoimmune encephalomyelitis. Nature 1988; 331: 265-7.

38 Mattingly JA, Waksman $\mathrm{BH}$. Immunological suppression after oral administration of antigen I. Specific suppressor cells formed in rats Peyer's patches after oral administration of sheep erythrocytes and their systemic migration. J Immunol 1978; 121: 1878-82. 